\title{
Investor Sentiment and Stock Price Movement Property Sector in Indonesia Stock Exchange
}

\author{
Tri Kunawangsih Purnamaningrum* \\ Faculty of Economics and Business \\ Universitas Trisakti \\ Jakarta, Indonesia \\ *tri.kunawangsih@trisakti.ac.id
}

\begin{abstract}
This purpose of this research is to analyse the effect of sentiment investor (behavioural finance), fundamental macro economy and fundamental finance of corporate towards the property stock price listing in Indonesia Stock Market. Fundamental macro economy using two proxy variable are growth of PDB and interest rate. Fundamental finance of corporate also using three proxy variable are current ratio, $\mathrm{ROE}$, dividend per share and index Straits Times. The data used in this research was quarterly data during period 2011-2016. The study was conducted on 17 companies the property (408 observation). The estimation method is based on pooled Ordinary Least Square regression with random effects model. The results of this study shows economic growth and interest rate had negative significant toward property stock price. Current ratio, dividend per share and straits times index had positive significant toward property stock price. ROE has negative significant. In this research sentiment investor is quasi moderating variable.
\end{abstract}

Keywords-sentiment investor, behavioral finance, fundamental macroeconomic and microeconomic, property stock price

\section{INTRODUCTION}

Investment activities have an important role in driving the economic growth of a country. Increased investment activities carried out by the community will increase capital that is needed in production activities. The development of investment in the capital market is not only influenced by macro variables but also influenced by investor behaviour. Investor decisions in the capital market are influenced by purchasing power, experience, level of knowledge and information. The diversity above forms the level of confidence and expectations of the return and risk of the investments made.

A growing capital market can be used as an indicator of a country's economic health. The increase in the Composite Stock Price Index illustrates the increasingly active capital markets in Indonesia. The capital market has a strategic role in driving a country's economic growth. Even the capital market is also a measure of the modernity of a country [1].

The assumptions used when conducting an analysis, each economic actor will make rational decisions. But in reality, investors do not always behave rationally, when investing. Facts prove so many events in the world that show that investor behaviour is irrational. The financial crisis (market crash) that occurred since 1929 until the last few years is proof that investor behaviour is not entirely rational. History records that the world economic / financial crisis since the Great Depression of 1929 until now has happened 61 times [1].

Shiller [2] then concluded that the uncontrolled actions of investors were not caused by macro and microeconomic fundamentals but were motivated by psychological factors. Psychological factors that hit investors were fear, greed and madness which were very dominant at that time. Under these conditions, the analysis of stock price movements is not only based on the classical financial model, but with a more approach towards the psychology of the investor community or referred to as investor sentiment. The new approach is considered abler to explain how the decision-making process of investors is known as behavioural finance. This theoretical approach sees that investment is no longer seen as a rigid theory, but rather a theory that includes aspects of psychology that influence an investor in making decisions.

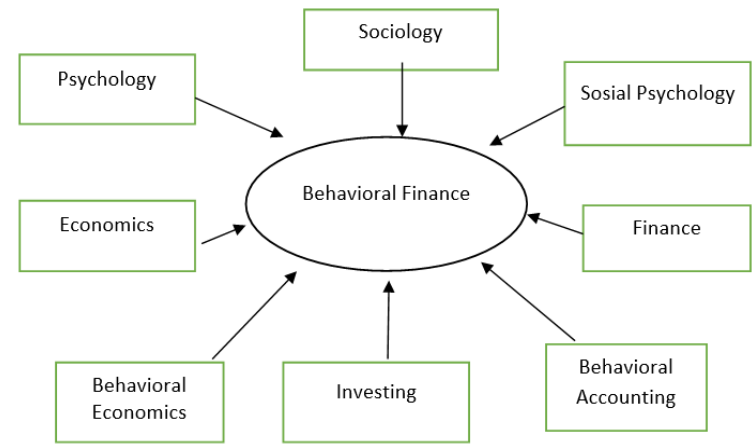

Fig. 1. Interdisciplinary financial behavior

Behavioural finance is built on various assumptions and ideas of economic behaviour. The involvement of emotions, traits, preferences and various things inherent in humans as intellectual and social creatures will interact which then underlies the emergence of a decision to take an action as shown in the figure 1 [3]. 
In psychology literature it is found that someone makes systematic mistakes in the way of thinking (cognitive) such as being too sure of their abilities and expertise, relying too much on experience and others. A wrong or irrational decision occurs because someone has a bias in trust. Trust bias occurs under conditions of uncertainty explained in heuristic psychological theory. While trust bias under certain risk conditions is explained in the prospective psychological theory [4]. Both psychological theories are theoretical frameworks that underlie behavioural finance [5].

The property sector is one sector that is capable of absorbing large numbers of workers and has a multiplier effect, as well as considerable backward linkage to other economic sectors. The facts show that the stock prices in some property sector issuers decreased when the company experienced an increase in profits. This is also shown in the relationship between trading volume and the price of shares in the sector. The increase in trading volume does not have an impact on rising stock prices. Seesaw sentiment shows that high sentiment is associated with high stock valuation, and conversely low sentiment works in the opposite direction.

Studies of investor sentiment and its influence on stock returns have been carried out in developed countries such as the United States. But researchers face difficulties when conducting studies on investor sentiment, mainly through direct observation. Therefore, the researchers used various proxies to measure investor sentiment such as trading volume, premium dividends, close-end fund discounts, the number of IPOs, IPO yields on the first day. The results of his research show that when sentiment levels are high, the returns for stocks at risk will be lower than stocks that are less risky, and vice versa for the case of low sentiment levels.

\section{LITERATURE REVIEW}

Investment is the placement of funds or a number of capitals made by investors to get profits in the future. An investment is the sacrifice of assets owned now to obtain assets in the future with greater amounts.

Baker et al [6] in their study entitled "Investor Sentiment in the Stock Market", shows that when the level of sentiment is high, the returns for shares at risk will be lower than shares with less risk, and vice versa for the case of level low sentiment.

Paudel and Laux [7] in their study entitled "A Behavioural Approach to Asset Pricing", shows that investor sentiment and stock prices have an insignificant relationship.

Sayim and Rahman [8] conducted a study with the title, "The relationship between individual investor sentiments, stock returns and volatility: Evidence from the Turkish market, shows that investor sentiment has a significant positive effect on stock returns. The theoretical framework as in figure 2.

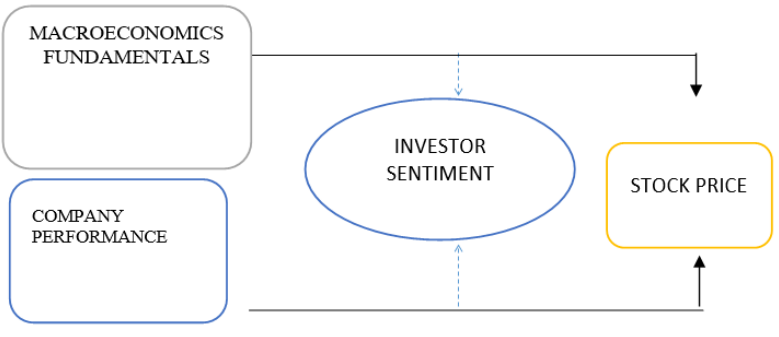

Fig. 2. Theoretical framework.

Hypothesis: Investor sentiment moderates the effect of corporate performance on macroeconomic fundamentals, and the straits times index on property sector stock prices

\section{METHODS}

Investor sentiment is defined as confidence in future cash flows and investment risk that is not supported by fundamental information. Ignoring investor sentiment is very risky and expensive [6,9].

TABLE I. MACROECONOMIC VARIABLE OPERATIONAL DEFINITIONS

\begin{tabular}{|l|l|l|l|l|}
\hline No & Variable & \multicolumn{1}{|c|}{$\begin{array}{c}\text { Variable } \\
\text { Definition }\end{array}$} & \multicolumn{1}{|c|}{ Measurement } & \multicolumn{1}{|c|}{$\begin{array}{c}\text { Data } \\
\text { Source }\end{array}$} \\
\hline 1. & GGDP & GDP growth & $\begin{array}{l}\text { National Output } \\
\text { Growth. }\end{array}$ & BPS \\
\hline 2 & BI Rate & Interest rate & $\begin{array}{l}\text { Basic interest rates } \\
\text { by Bank Indonesia. }\end{array}$ & BI \\
\hline
\end{tabular}

\section{COMPANY FINANCIAL PERFORMANCE}

TABLE II. OPERATIONAL DEFINITION OF COMPANY PERFORMANCE VARIABLES

\begin{tabular}{|c|c|c|c|}
\hline No & Variable & Variable Definition & Measurement \\
\hline 1 & $\begin{array}{l}\text { Current } \\
\text { Ratio } \\
(\mathrm{CR})\end{array}$ & $\begin{array}{l}\text { The amount of the } \\
\text { company's current } \\
\text { liabilities that are } \\
\text { guaranteed payments } \\
\text { by current assets }\end{array}$ & $\mathrm{CR}=\frac{\text { Current Asset }}{\text { Current Liabilities }}$ \\
\hline 2. & $\begin{array}{l}\text { Return } \\
\text { on Equity } \\
\text { (ROE) }\end{array}$ & $\begin{array}{l}\text { Measuring the ability } \\
\text { of an issuer to } \\
\text { generate profits with } \\
\text { equity capital } \\
\text { invested } \\
\text { shareholders }\end{array}$ & $\mathrm{ROE}=\frac{\text { Net Profit }}{\text { Total Equity }} x 100 \%$ \\
\hline 3 & $\begin{array}{l}\text { Divident } \\
\text { per Share } \\
\text { (DPS) }\end{array}$ & $\begin{array}{l}\text { Measuring the } \\
\text { amount of dividend } \\
\text { distribution per share }\end{array}$ & DIV $=\frac{\text { Dividend }}{\text { number of shares outstanding }}$ \\
\hline 4. & $\begin{array}{l}\text { Index } \\
\text { Strites } \\
\text { Times }\end{array}$ & $\begin{array}{l}\text { Composite stock } \\
\text { index representing } \\
\text { Singapore. }\end{array}$ & $I S T=\sum \frac{(P x Q)}{N d} x 100$ \\
\hline
\end{tabular}

Sources: BEI \& Yahoo Finance 
The population of this research is property companies listed on the Indonesia Stock Exchange (IDX). Sampling uses a purposive sampling method, which is a sample selection technique using certain predetermined criteria. The sample selection criteria are as follows: the company is engaged in property listings consistently on the IDX during the period 2011-2016, and companies engaged in the property sector that consistently provide dividends during the 2011-2016 period. This research method uses pooled ordinary least square panel

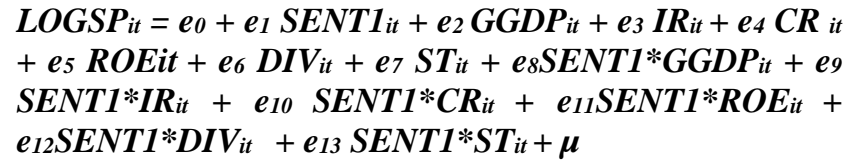

\section{RESULTS AND DISCUSSION}

The $\mathrm{R}^{2}$ value is used to measure the level of variation in changes in the independent variable on the dependent variable. The higher the value of $\mathrm{R}^{2}$ means the better the prediction model of the proposed research model. The processing results for the fit model are shown with a coefficient of determination of $34.70 \%$, it means that the behaviour of the independent variables are SENT1, GPDB, IR, CR, ROE, DIV, ST and the interaction between investor sentiment with the six variables is able to explain the behaviour of the dependent variable that is, the stock price of 0.349997 while the remaining $65.30 \%$ is a variation of other independent variables that affect the value of the stock price but is not included in the model. Regression results show that investor sentiment has a significant effect on stock prices, if investor sentiment rises $1 \%$ it will reduce stock prices by $0.002724 \%$. The GDP growth variable has a significant effect on stock prices, if GPDB rises $1 \%$ it will reduce the property sector stock prices by $0.404211 \%$. Interest rates have a significant negative effect, where if there is a $1 \%$ increase in interest rates will reduce the stock price by $0.091408 \%$.

Dividend policy is one of the powerful variable, it explored in developed and developing countries may be different [10]. Corporate financial fundamental variables which are proxy by current ratio, ROE and Dividend per share, all variable have a significant effect on the stock price of the property sector. If CR increases by $1 \%$, it will increase the stock price by $0.075306 \%$. If ROE rises by $1 \%$ it will reduce the stock price by $0.001339 \%$. Increase in the Straits Times index will raise the stock price of the property sector on the IDX up $0,000253 \%$

\section{CONCLUSIONS}

The investor sentiment variable tends to be a quasimoderating variable. This means moderating the relationship between the independent variable with the dependent variable which is at the same time an independent variable. Fundamental macroeconomic reflected by economic growth and interest rates have a significant negative effect on stock prices in the property sector. Fundamental Financial performance reflected by the Current Ratio and dividend per share and the strait times index has a significant influence on stock price. While the ROE variable has no significant negative effect on the stock price of the property sector.

Education about the role of the capital market to the community since teens to improve financial literacy. Further research is needed to assess stock prices using a more diverse investor sentiment proxy. Add and expand the research sector outside of property companies so that results can be generalized. Related technological progress and information, then further studies can be using primary data

\section{REFERENCES}

[1] S. Widiatmodjo, Pengetahuan Pasar Modal untuk Konteks Indonesia. Penerbit PT Elex Media Komputindo: Kompas Gramedia, 2015.

[2] R.J. Shiller, "Do stock Prices Move too Much to be justified my sub sequent Changes in devidens?" The American Economic Review, vol. 71, no. 3, pp. 421-436, 1981

[3] V. Ricciardi and H.K. Simon, "What is behaviour in Finance?" Business, Education and Technology Journal, pp. 1-9, 2000.

[4] I. Alsedrah and N. Ahmad, "Behavioral Finance: The missing piece in modern finance," Proceedings of the First Middle East Conference on Global Business, Economics, Finance and Banking (ME14 DUBAI Conference) Dubai, 2014

[5] M. Khoshnood and Z. Khoshnood, "Behavioral finance: A new paradigm in finance," Information and Finance, vol. 21, pp. 96-100, 2011

[6] M. Baker, J. Wurgler and Y. Yuan, "Global, local, and contagious investor sentiment," Journal of financial economics, vol. 104, no. 2, pp. 272-287, 2012.

[7] J. Paudel and J. Laux, "A Behavioral Approach to Asset Pricing," The Journal of Applied Business Research, 2008.

[8] M. Sayim and H. Rahman, "The relationship between individual investor sentiment, stock return and volatility: Evidemce from the Turkish market," International Journal of Emerging Markets, vol. 10, pp. 504-520, 2015

[9] H. Shefrin, A Behavioral Approach to Asset Pricing. 2nd edition. San Diego: Elsevier, 2008

[10] W.R. Sari, "Dividend Policy of Indonesian State-Owned Enterprises," Telaah Bisnis, vol. 18, no. 2, pp. 33-44, 2017. 